Submitted $25^{\text {th }}$ June 2021

Accepted $30^{\text {th }}$ June 2021

\title{
A STUDY ON THE USE OF MIXED LANGUAGE IN TEACHING ENGLISH AT HOSPITALITY MANAGEMENT CLASS
}

\author{
Ni Luh Supartini ${ }^{1}$, Ni Putu Oka Agustini ${ }^{2}$ \\ Institut Pariwisata dan Bisnis Internasional, Indonesia \\ Politeknik Pariwisata Bali, Indonesia \\ supartini@stpbi.c.id \\ okaagustini@yahoo.com
}

\begin{abstract}
Learning English as a foreign language required some strategies to achieve the goal of communication. In teaching and learning process, the teacher and students frequently use their first language to explain the difficult word in English. This study aimed to investigate the language used by the teacher as communication strategies in teaching English as a foreign language and students' responses toward the use of each type of language instruction in teaching English at Hospitality class. To investigate the study there were 2 teachers and 2 classes of hospitality management class as the subject. The data were collected through observation of teaching and learning process and interview session. The study was designed as descriptive qualitative research and the data were analyzed descriptively. The finding showed that the teacher used the target language frequently, however the used of mixed language to explain some difficult words also found in teaching and learning process.
\end{abstract}

Keywords: mixed language; communication strategies; teaching English

\section{INTRODUCTION}

The students in hospitality are required to have good communication in English. English as the most essential subject should be mastered for their future jobs. They have to communicate with foreigners from different countries. Hospitality with a good communication skill are the keys for giving services to the guest. Therefore, the students encourage to have good communication of this international language.

During English learning, the students commonly face some problem in the classroom. In Indonesia, English is not their first language. When doing a communication, the participants (students and teacher) usually face many obstacles or problems and one of it is miss- communication among the participants. Therefore, the participants require to know the strategies about how to transfer a message or information correctly. The ways which help people to solve communication problem is called communication strategies (Moattarian and Tahririan, 2013).

The term of communication strategies (CS) is used by people in attempting 
to communicate in the foreign or second language with a reduced interlanguage system. They find that the target language items or structures to convey their messages are not available. In order to keep communication steady, speaker may circumvent linguistic difficulties by changing or reducing the content of their messages. In other words, the speakers may avoid reference to a concept or topic in order to overcome the lack of the target language term or expression needed to convey this meaning. These strategies are usually known in the field of second language acquisition (SLA) especially communication strategies as "avoidance" (Tarone, 1981) or "reduction" (Færch and Kasper, 1983). More often, speakers are able to keep their communicative goals and convey the original content of their messages by developing an alternative means of expression. People can also use the similar terms, a descriptive circumlocution, a word coinage, a native language transfer, a gesture or an appeal for assistance to achieve the goal of communication. These different kinds of techniques might be used to compensate for or avoid all sorts of interlanguage deficits: lexical, grammatical, pragmatic or sociolinguistic.

Target language is defined generally as the language that someone wanted to learn besides their L1 or L2. British Council, (2017) stated that target language can be defined as the language learners are studying, and also the individual item of language that they want to learn, or the teacher wants them to learn. Littlewood and $\mathrm{Yu}$ (2011) also stated that the rationale as well as the benefit for using only the target language in the classroom is that the more students are exposed to English, the more quickly they will learn. As they hear and use English, they will internalize it to begin to think in English and it is become the only way to them to learn the target language because they are forced to use it. In short, by using target language only the students can improve their proficiency level of the language and can use that language as natural as they can in their real communication. Besides that, another expert like Harbord (1992) and Pennycook (1994) stated that the use of target language in this case is English as the tool for communication in the learning process is implied as the ideal way to teach the target language and the teacher can use direct method to teach in the classroom (cited in Miles, 2004). In the Direct Method, the students will use the target language in the learning process, and then it can make them familiar with the target language. Because they are already familiar with that language, they can begin to think and speak with that target language (English) only. In the other words, the more both of the teacher and students use the language, the more they learn about that language. In short, through the use of target language only, it can make both students and teacher improve their vocabulary, they can directly think by using the target language itself, and speak with the target language itself. The language used in the EFL classroom also becomes Harmer concerns. Harmer (2007) stated that when conducting the learning process, the teacher also could play eight roles as the teacher. One of the roles which have a close relation with the language is teacher as a prompter. It means that the teacher seen as a guidance and motivator for the students to speak the target language only by giving an example.

Besides the target language, there is also mixed language refers to language of instruction. According to Chan and Abdullah (2015), mixed language is familiar as bilingual or two languages or more in which both a native language and a second language are taught as subject and both could be use as language of instruction. $\mathrm{He}$ 
stated that some benefit of using mixed language such as to encourage students to have a sense of integration and equal among themselves, a step to obtain the means to communicate socially and effectively. It leads the students to understand the materials easier. Interlanguage is continuum between the first language and the target language along which all learners traverse (Brown, 2000). The term interlanguage was firstly used by John Reinecke in 1935. He always used interlanguage to refer nonstandard variety of a first or second language used as a means of intergroup communication. Foreign language learners may encounter various communication problems when their interlanguage is limited. In order to convey their messages and remain in a conversation until their communication goal is reached, EFL (English as a Foreign Language) learners need to employ communication strategies (CS), which have been defined generally as devices employed by L2 learners to overcome perceived barriers to achieving specific communication goals (Færch \& Kasper, 1983). Analysis of these strategies provides us with rich insights into the complex process of language acquisition and enables us to generate ideas for developing strategies to improve language learners' interlanguage skills. Language learners' interlanguage development is influenced by their ability to use CS.

A study about the language used either target language only and mixed languages has been conducted from some researchers like Choi and Leung as well as Sharaeai. A study entitled Use of First and Foreign Language as Learning Resources in a Foreign Classroom by Choi and Lueng (2017) investigated about how the different languages used by an experienced teacher in classroom interaction as well asto facilititae learning process in EFL classroom. Another researcher from Sharaeai (2012) entitled students perspectives on the use of L1 in EFL classroom. The aimed of this study was to help both teachers have an understanding about the reason and perspective of the students ${ }^{\text {ee }}$ use their first language mostly in English classroom. Moreover, it also attempted to help the students to have a better understanding about the importance of the use of foreign language (English) in their English class so then, they can eliminate the use of their first language gradually. Supartini (2015) also conducted a study about communication strategies used in teaching English as a foreign language. She found that the students refer to use their L1 to express the difficult idea when communicate using English.

Besides English for foreign language, the familiar term use is English for specific purposes (ESP). ESP refers to teaching English to university students or people already in employment, with reference to the particular vocabulary and skills they need. ESP for tourism and hospitality are also challenge for the lecturers to use mixed language during teaching and learning process. Since the students mostly from local students in which English is not their first language. Based on the phenomenon above, the researcher finds it interesting to conduct a study about mixed language used by the teacher and students in ESP class especially for hotel management students. This research on purpose to find the form of language instruction in which part of communication strategies during teaching and learning process. 


\section{METHODOLOGY}

This study was followed qualitative, interactive, and descriptive approach, model, and design by adopting the framework of Maxwell (2012). The data was collected from a primarily resource by using observation, recording and interview. In observation, the researcher was the main instrument and audio recorder as the tools to record the utterances in the learning process. Interview was done with teacher and also students. Data were also collected through in-depth interviews with the subjects.In this study, two teachers and four students as the subject in this study.

They are provided with some questions regarding the language used in teaching and learning process. After all the data was collected, then those data were analyzed descriptively by following the framework from Miles and Huberman (1994). There were three major phases to be followed; data reduction through transcribing and classifying, data display by presenting the data after done the classifying in the form of table, and conclusion drawing as well as verification through concluding and verifying or double checked.

In conducting a qualitative study, it is important for the researcher to collect, analyze and present the data that could be trusted. It is due the wide chance provided by a qualitative study for the researcher to be subjective in collecting and interpreting the data, which later could cause bias in the result of the study. Therefore, trustworthiness of the study in a qualitative research is merely needed. The trustworthiness of the result could be done through triangulation

\section{RESULTS AND DISCUSSION}

This present study found kinds of language instruction used and students' respond towards the use of language of instruction as communication strategies in teaching English in Hospitality Management Class. The finding of language used can be seen in the following table 1 and chart 1 .

Table 1. Language Used by Teacher and Students

\begin{tabular}{|l|l|c|c|}
\hline No & Language Used & Teacher & Students \\
\hline $\mathbf{1}$ & Literal translation & V & V \\
\hline $\mathbf{2}$ & Language switch & V & v \\
\hline $\mathbf{3}$ & Mime & V & v \\
\hline
\end{tabular}




\section{Chart 1. Distribution of Language Used by Teacher and Students}
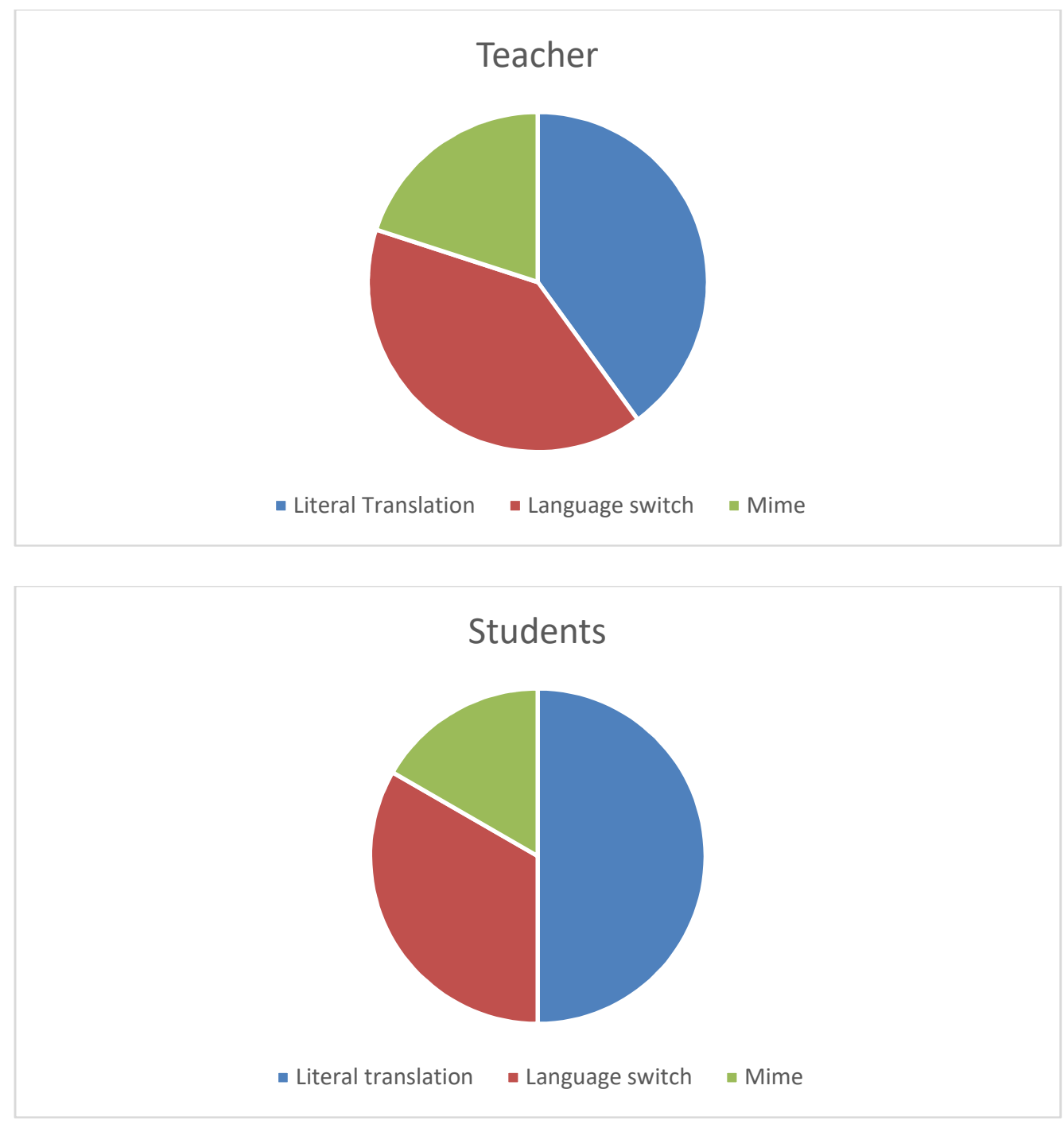

From the table and chart above, it was found that three kinds of mixed language used can be categorized as interlingual strategies. It included literal translation, language switch and mime. Interlingual strategies are strategies occupied by the speaker to get the goal of communication in which involves the first and target language. Those three kinds of strategies were used during teaching and learning observation. The students and the teacher mixed their first language and the target language in order to communicate in the classroom. Many of utterances are produced by language learners are supposed as ungrammatical. They contain of a lot of mistakes in lexis, pronunciation and grammar. Ellis (1989) mentions the characteristics of learner' talk such a: interlanguage is dynamic and influenced by the learners.

The teacher frequently used language switch in explaining the materials. From the observation, the students looked confused when the teacher used the target language. Directly the teacher used the first language in order to emphasize the 
point of explanation. Language switch is the use of first language and the target language for communication. The use of this strategy is to improve students' understanding rather than talk with the target language and getting the students confused.

The example of language switching used by the teacher can be seen in this utterance:

\author{
Teacher: "Do you understand? \\ Students: silent \\ Teacher: Kalian mengerti?" \\ Students: Yes.......
}

The students were not responded while they are given questions using target language, however when the teacher change the language into their first language, they directly answered using the target language. This seems that the students did not understand or they are confused about the answer. It is commonly happened to local teacher who used mixed language to get the students responds in teaching foreign language.

Language switching, literal translation and also mime are the most frequent strategy used to explain some difficult words. Sometimes, the teacher only translated one word into the first language as the clue to lead the students' understanding. Some vocabularies which is related to hospitality that they are not familiar with, should be translated into the first language. For example the word cutleries, should be translated as perlengkapan table manner.

In other hand, not only the teacher used mixed language in the classroom. The students also felt difficult when they are provided with some questions and should answer it in English. They also translated the sentences into the first language and trying to complete it with the target language. The language used were mixed between the first and target language.

It can be concluded that the teachers used first language only when they explained difficult or new words. Both teachers first attempted to explain the words and meanings of complex ideas in English, but resorted to first language when they thought the students could not understand their English explanations.

Not only explain the words, in giving instructions, the teachers used first language only after first giving instructions in English to make sure that their students were understand what was said. Since it was quite noise in those classes at the time, the teacher also used first language instructions to discipline the students so they were clear that their teacher wanted their attention. These two class observations indicated that first language was used on situations when English explanation does not work smoothly therefore the first language takes role to facilitate and support the English teaching learning in the classroom. One of them said that she used the first language when she teaches English, was most necessary to help define some abstract words or when they try to introduce new vocabulary, while explaining difficult concepts or ideas, giving instruction, and disciplining the class share the same percentage.

Furthermore, the strategies also used by the teacher was using mime. 
Mime is a nonverbal portrayal of thought or narrative through gesture, body movement, and facial expressions. Despite the nonverbal nature of mime, it can be a potent communicative teaching tool. Mime or gesture were used to describe that were difficult to say in the first language. The teacher tried to expressed the idea using gesture to explain the word meaning. During classroom observation, most students have difficulties to express what they really mean to say. One of the reasons is because they have difficulties to internalize the meaningful grammar piece and use right grammar that conveys the right meaning in practice. The teacher need to make sure that the appropriate mimes which are easy enough to mime and guess the meaning of words or sentences. Mime sessions in EFL classes require students to interact in pairs or groups, collaborate to reach agreement on how to conduct their roles, dialogues, and stories. Through mime, students learn how to interact in different situations, ask questions, and make contributions or express themselves; thus, enabling a constant interchange of language that seem more real-world and natural, because they have to behave as they would in their usual interactions with people out of class. Finally, using gestures and actions to dramatize experiences and situations through mime, bring an EFL oral communication class to life and provides a framework in which students have a need to communicate and convey their emotions, thereby improving the quality and authenticity of their communicative messages.

Norton and Kramsch (2000) comment that "identities and lived experiences of language learners are already part of the language learning/language teaching experience whether or not this is formally recognized in the target language curriculum." The purpose of the mime activity employed in the current study is to practice the language of confirming understanding in an interactive manner and to put the learner in the center of learning in a communicative settings.

Many researchers such a study conducted by Greggio \& Gil (2007) argued that language switching can be an important element in contributing English language teaching and learning process. Some opinion about language switching as an opportunity for language development as it allows the effective transfer of information from the senders to the receivers (Skiba, 1997). In other words, it can be exploited as a teaching method for teaching second or foreign languages or it can ease language development as a means for providing language samples (Cook,1991). Although, language development is seen to be minimal and slow, language switching is still perceived as a positive indication of the learning progress.

The focus of the class often determines how much exposure gets placed on using or limiting the first language in the classroom. In some schools that provides native speaker as an English teacher may often be better served if students try to use English as much as possible. When a student cannot understand a word or utterance, or cannot follow the teaching learning process, then he/she has the chance to interpret the meaning by looking at the situation. But in the school that English only seen as a supplementary subject, then the focus is only for introduction. Students practice in English with the vocabulary introduction only provided by the teacher. In general, when students can use their first language to ask questions and 
confirm their misunderstanding or confusion, it often leads to a clearer realization of the form and meaning of the language. Lower-grade level students may also need further explanation and clarification on some points of the new materials. It should be noted that the teacher can sometimes use the first language to help students produce utterance beyond their ability. Students produce utterance in their first language then the teacher translates and ask them to repeat after her/him. The teacher might also consider using the L1 in the English classroom to shortcut the time. An explanation in first language may be necessary with a class of where no one speaks English. A student may get stuck in a teaching learning process and find themselves unable to express their opinions, answers, or ask the questions. Therefore, the teacher can simply allow them to use their first language but stimulate them to say it again in English with the teacher' help.

\section{CONCLUSION}

This study showed that the used of mixed language in English classroom is very important especially for students who learn English for specific purposes. Some vocabularies were not familiar with them enforce them to explain it using mixed language. It hoped that finding will make other people realize that the use of first language has a lot of roles classroom. It also did not reduce the students' exposure to use English. By referring to some related theories and researches of the use mixed language in English classroom, it can be seen that the use of first language has an important role and can facilitate all aspects of language instructions. It indicates that the first language gains more benefits by incorporating students first language as a learning tool and a facilitator for an efficient teaching. Mixed language is most useful at beginning and low level. Mime is also effective as it provides students with motivation to generate language even if this motivation is purely derived from performing their mime in front of other class members.

For further researchers are suggested to explore another area of the use mixed language as communication strategy. Not only in English classroom, but also in another interaction such as tour guide, hospitality area, etc. The result might show how important the first language in learning the target language.

\section{REFERENCES}

Bialystok, E. (1990). Communication Strategies: A psychological analysis of second language use. London: Blackwell

Brown,H.D. (2000). Principles of Language learning and teaching. ( ${ }^{\text {th }}$ Edition). NY: Longman

Greggio, S. \& Gil, G. (2007). Teacher's and learner's use of code-switching in the English as a foreign language classroom: a qualitative study. Linguagem and Ensino, 10 (2),371-393

Hanive. (2003). Reasons for the teachers' uses of code-switching in adult EFL 
classroom. Hasan Ali Yücel Eğitim Fakültesi Dergisi Sayı 20 (2013-2) 6982 .

Hua, Nor\&Fariza. (2012). Communication Strategies Among EFLStudents- An Examination of Frequency of The Used of Communiation Strategies. GEMA Online ${ }^{T M}$ Journal of Language Studies 836 Volume 12 (3).

Inbar-Lourie, Ofra. (2010). English only? The linguistic choices of teachers of young EFL learners. International Journal of Bilingualism vol. 14 no. 3, p 351-367.

Lam, W. and Wong, J. (2010). The affects of strategy training on developing discussion skills in an ESL classroom», ELT Journal, 54, 3: 245-255.

Littlemore, Jeannete. (2003). An Empirical Study of the Relationship between Cognitive Style and The Use of Communication Strategy. 'Applied Linguistics 22.2:241-65.

Mei and Nathalang (2010). Use of Communication Strategies by Chinese EFL Learners. Chinese Journal of Applied Linguistics (Bimonthly) June 2010 Vol. 33 No. 3.

Reineman. J. (2001). Using the first language in second language instruction. TESL-EJ Forum. Retrieved from http://www.aitech.ac./iteslj./html

Tien, C \& Liu, K. (2006). Code-switching in two efl classes in Taiwan. In A. Hashim \& N. Hassan (Eds). English in Southeast Asia: Prospects, perspectives and possibilities. Kuala Lumpur: University Malaya Press. 